\title{
触 New Disease Reports \\ Alternaria cucumerina causing leaf spot of pumpkin newly reported in North Caucasus (Russia)
}

Ph.B. Gannibal

\author{
All-Russian Institute of Plant Protection, shosse Podbelskogo 3, 196608 Saint Petersburg, Russia
}

*E-mail: phbgannibal@yandex.ru

Received: 05 May 2011. Published: 30 Jun 2011. Keywords: alternariosis, Cucurbita maxima, fungal plant disease

Alternaria cucumerina is an important pathogen of some Cucumis, Cucurbita and Citrullus species with a wide distribution, including several European and Asian countries (Ellis, 1971). Alternaria leaf blight can cause up to 30\% yield loss (Latin, 1992) and lead to a decrease in soluble solid content in fruits (Latin et al., 1994). The fungus has been found in the Far East of Russia on Cucumis melo, Cucumis sativus and Citrullus lanatus (Egorova, 1999); however it has not been reported from other areas of Russia. At the end of July 2009, foliar necrosis of pumpkin (Cucurbita maxima) was observed in private gardens located in the Republic of Dagestan (North Caucasus region; $41^{\circ} 51^{\prime} 12^{\prime \prime} \mathrm{N}, 48^{\circ} 25^{\prime} 58^{\prime \prime} \mathrm{E}$ ). Leaf blight was accompanied by powdery mildew. The observed leaf spots were up to $8-12 \mathrm{~mm}$ in diameter with a round greyish to pale brown centre and dark brown edges. Up to $30 \%$ of the surface area of older leaves was affected by the disease. Fungal isolates with morphological characteristics similar to those of A. cucumerina were collected from diseased leaves and cultured on V4 medium ( $150 \mathrm{ml}$ juice mixture [beet, celery, carrot, tomato 4:3:2:1] and $20 \mathrm{~g}$ agar/l; Mikhailova et al., 2002) then incubated at $24^{\circ} \mathrm{C}$ under a light/dark cycle $(12 / 12 \mathrm{~h})$. After seven days, large solitary conidia were formed on the surface of the agar. The average size of the conidia was 70-94 x 22-25 $\mu \mathrm{m}$ with a conidial beak length of 40-145 $\mu \mathrm{m}$. In general, these measurements are within the size range determined by Simmons (2007) for A. cucumerina. On potato-carrot agar, the conidial body was smaller $(43-70 \times 16-20 \mu \mathrm{m})$, whereas the beak was appreciably longer $(70-220[-284] \mu \mathrm{m})$.

Two isolates (MF-P288011, MF-P288021) were evaluated for their pathogenicity on leaves of Cucurbita moschata cv. 'Vitaminnaya' grown in pots under greenhouse conditions. Four plants per isolate were inoculated by spraying the leaves with a suspension containing approximately equal numbers of conidia and mycelial pieces $(50000 \mathrm{cfu} / \mathrm{ml})$. Control plants were sprayed only with water. After inoculation, plants were incubated in a chamber with a high relative humidity (nearly 100\%) for 24 hours. The plants were placed back in the greenhouse where brown spots were observed on all plants three days post-inoculation. No symptoms were observed on non-inoculated plants. Seven days after inoculation, $20 \%$ of the leaf surface was diseased. Older leaves had a higher number of larger spots than younger leaves. Koch's postulates were confirmed by re-isolation of the fungus from inoculated plants. To our knowledge, this is the first documented detection of A. cucumerina in North Caucasus, one of the main areas of production of pumpkins and other cucurbitaceous crops in Russia.

\section{References}

Egorova LN, 1999. The genus Alternaria and allied hyphomycetes from the Russian Far East. Mikologiya i Fitopatologiya 33, 13-18.

Ellis MB, 1971. Dematiaceous Hyphomycetes. Kew, UK: CAB International Mycological Institute.

Latin RX, 1992. Modeling the relationship between Alternaria leaf blight and yield loss in muskmelon. Plant Disease 76, 1013-1017.

[doi:10.1094/PD-76-1013]

Latin RX, Rane KR, Evans KJ, 1994. Effect of Alternaria leaf blight on soluble solid content of muskmelon. Plant Disease 78, 979-982. [doi:10.1094/PD-78-0979]

Mikhailova LA, Gogoleva SG, Gultyaeva EI, 2002. The interactions of Bipolaris sorokiniana strains and wheat samples. Mikologiya $i$ Fitopatologiy 36, 63-66.

Simmons EG, 2007. Alternaria: An Identification Manual. Utrecht, Netherlands: CBS Fungal Biodiversity Centre.

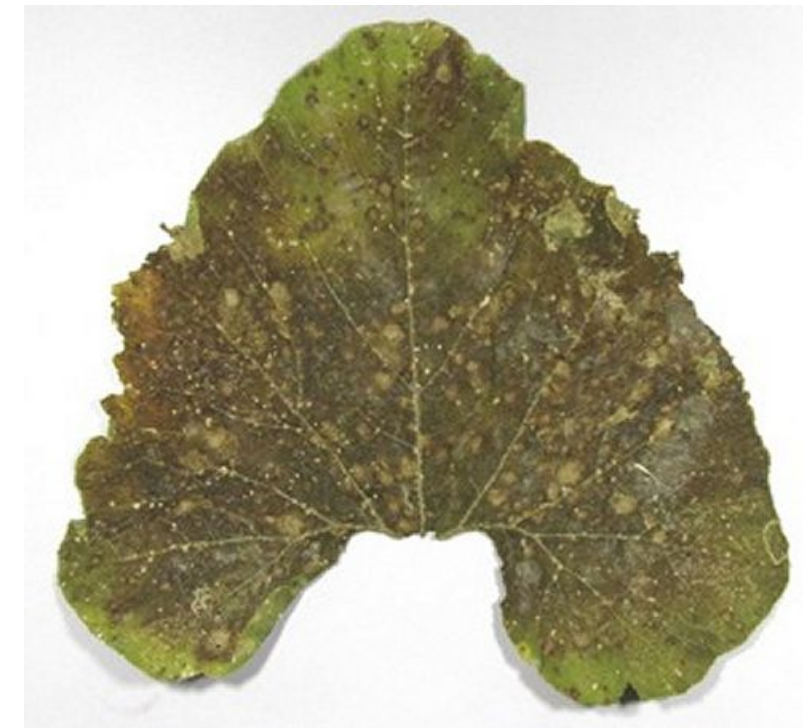

Figure 1

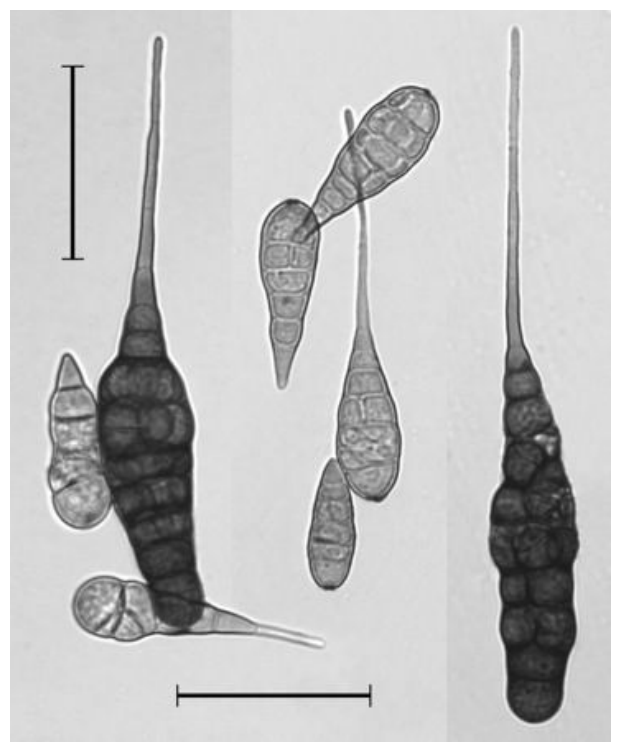

Figure 2

To cite this report: Gannibal PB, 2011. Alternaria cucumerina causing leaf spot of pumpkin newly reported in North Caucasus (Russia). New Disease Reports 23, 36. [doi:10.5197/j.2044-0588.2011.023.036] 